\title{
EMPATI KULTURAL PADA MAHASISWA
}

\author{
Neng Gustini ${ }^{1}$
}

\begin{abstract}
Cultural empathy is the ability to feel what another person by an individual or a community group. Culture of others became the foundation behave in every interaction that exists. Empathy has the potential to transform differences into mutual understanding and deep understanding. Similarly, in guidance and counseling, a counselor absolutely have skills in counseling, one of which he must have a sense of empathy. Therefore, empathy is very important, both for educators and for counselors, especially for counselors, provide a sense of comfort to the counselee as if a counselor was feeling what counselees feel and recognize themselves in more depth. As for cultural empathy in counseling is very important for the counseling process is a process aid through the interaction between two individuals of different cultural backgrounds. One problem that often arises is the lack of empathy in communication that could lead to a misunderstanding in interaction. Whereas, the purpose of cultural empathy is to gather information and to establish a therapeutic alliance. This study aims to investigate and describe the cultural empathy in students. This study uses a quantitative approach with descriptive methods, instrument using a questionnaire and the sample was 83 students of UIN Sunan Gunung Jati Bandung. The findings of this research is cultural empathy of student UIN Sunan Gunung Jati Bandung categorized as being with an average by score of 83.84 .
\end{abstract}

Keywords: Cultural, Empathy.

JOMSIGN: Journal of Multicultural Studies in Guidance and Counseling
Website : http://ejournal.upi.edu/index.php/JOMSIGN

Permalink: http://ejournal.upi.edu/index.php/JOMSIGN/article/view/6049

How to cite (APA): Gustini, N. (2017). Empati kultural pada mahasiswa. JOMSIGN: Journal of Multicultural Studies in Guidance and Counseling, 1(1), 17-34.

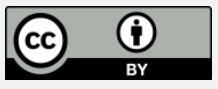

This is an open access article distributed under the terms of the Creative Commons Attribution 4.0 International License, which permits unrestricted use, distribution, and reproduction in any medium, provided the original work is properly cited.

\section{PENDAHULUAN}

Pada era global ini, teknologi berkembang secara pesat dan ekonomi pasar yang semakin kompetitif sangat berpengaruh terhadap perilaku remaja, khususnya mahasiswa, baik secara positif maupun negatif. Secara positif, remaja dengan mudah dan cepat menerima berbagai informasi tentang berbagai hal termasuk budaya untuk memfasilitasi perkembangan kognitifnya. Secara negatif, keadaan

\footnotetext{
${ }^{1}$ UIN Sunan Gunung Djati Bandung, Indonesia; gustine1981@uinsgd.ac.id.
} 
ini berpengaruh terhadap afeksi atau perkembangan emosionalnya; remaja dapat cenderung egois, memikirkan diri sendiri, yang mengakibatkan menurunnya tenggang rasa dan empati sosial terhadap orang lain, termasuk budayanya, serta mulai merenggangkan hubungan kekeluargaan dalam kehidupannya, lebih jauh lagi dapat menjadi penyebab terjadinya konflik sosial dan berdampak perilaku anti sosial di masyarakat.

Dampak negatif di atas dapat ditekan, jika remaja mampu mengembangkan perilaku empati. Perilaku empati dapat mereduksi intoleransi, konflik, diskriminasi dan meningkatkan pemahaman, rasa hormat, dan toleransi antara manusia dengan perbedaan etnis dan latar belakang budaya (Wang et al., 2003). Terdapat tujuh ahli atau teoretikus yang mengemukakan teori empati (Eisenberg, 1987; Fesbach, 1997; Davis, 1996; Hoffman, 1998 \& 2000; Batson, 1991, 1995, 1997). Mereka berpendapat bahwa empati merupakan kemampuan atau karakter atau bagian dari kepribadian individu dalam memahami perasaan dan pikiran orang lain (melibatkan proses afektf dan kognitif). Berdasarkan pendapat-pendapat tersebut, empati merupakan kemampuan individu untuk memahami keadaan orang lain, baik secara perasaan dan pikiran dengan mengomunikasikan pikiran dan perasaannya tersebut kepada orang lain tanpa kehilangan identitas dirinya sendiri atau dengan kata lain, empati merupakan kemampuan individu untuk menempatkan diri pada pikiran dan perasaan orang lain tanpa harus terlibat dalam perasaan maupun tanggapan orang tersebut.

Fenomena sosial menunjukkan bahwa perilaku empati mahasiswa di Indonesia menurun. Mereka cenderung bersikap individualistik, lunturnya nilai-nilai luhur kemanusiaan dan kemasyarakatan dari kehidupan, seperti tolong-menolong, kekeluargaan, kerjasama, kebersamaan, dan kepedulian kepada orang lain. Mahasiswa cenderung egois atau memikirkan kepentingan sendiri tanpa menghiraukan kepentingan bersama dalam masyarakat, bangsa, dan Negara. Kondisi ini cenderung akan menimbulkan suatu konflik dalam masyarakat dan terjadinya kesenjangan sosial. Mahasiswa juga akan dapat melanggar norma sosial dan norma agama yang ada, karena mahasiswa sebagai individu memiliki sifat egois atau mementingkan diri sendiri, dan tidak manusiawi dalam memperlakukan sesama manusia. Adapun penyebab merosotnya kemampuan berempati sangatlah kompleks.

Lingkungan tempat mahasiswa dibesarkan saat ini disinyalir meracuni kecerdasan berempati mereka. Sejumlah faktor sosial kritis yang membentuk karakter berempati secara perlahan mulai runtuh seperti pengawasan orang tua 
lemah, kurangnya teladan perilaku berempati, pendidikan spiritual dan agama relatif sedikit, pola asuh yang jelek, dan sekolah yang kurang memberikan stimulasi terhadap pertumbuhan empati. Selain masalah tersebut, mereka juga secara terus menerus menerima masukan dari luar yang bertentangan dengan norma-norma. Tantangan semakin besar karena pengaruh buruk tersebut muncul dari berbagai sumber yang mudah didapat, seperti televisi, film, permainan (game online), internet yang memberikan pengaruh buruk bagi kepribadian peserta didik karena menyodorkan pelecehan, kekerasan, dan penyiksaan (Borba, 2008). Fenomena menurunnya perilaku empati mahasiswa terhadap orang lain selaras dengan penelitian yang dilakukan Madina (2014) terhadap 215 mahasiswa $(56,86 \%)$ di salah satu Universitas Gorontalo menunjukkan bahwa mahasiswa memiliki perilaku empati yang sangat rendah. Oleh karena itu, sudah selayaknya perilaku empati ini dikembangkan di kalangan remaja, khususnya mahasiswa karena empati juga merupakan salah satu kunci untuk menciptakan hubungan terapetik (konseling) (Rogers, 1965). Banyak studi yang mengkaji perilaku empati di antaranya penelitian tentang Enhancing Empathy and Theory of Mind (Thalia R. Goldstein \& Ellen Winner, 2012), penelitian ini difokuskan pada anak-anak (usia SD) dan remaja awal (usia sekolah menengah), hasil penelitiannya menunjukkan bahwa empati mereka meningkat melalui bermain peran.

Perilaku empati ini juga banyak diteliti dalam seting budaya. Empati kultural (budaya) merupakan kemampuan untuk merasakan apa yang dirasakan orang lain oleh seorang individu atau suatu kelompok masyarakat. Budaya orang lain menjadi landasan bersikap dalam setiap interaksi yang terjalin. Ada empat ahli yang mengemukakan teori empati kultural (Pederson, 2008; Ridley \& Lingle, 1996; Wang, 2003, Tripti Bhaskar, 2011). Empati kultural sebagai kemampuan belajar dan keahlian pribadi yang berkaitan dengan kepribadian tertentu pada orang-orang dari kelompok etnis atau ras tertentu.

Dari pendapat keempat ahli di atas dapat disimpulkan bahwa terdapat kesamaan definisi empati kultural, meliputi pemahaman individu akan pengalaman diri orang lain dari budaya yang berbeda dan pemahaman akan informasi diri orang lain dengan menerjemahkan data-data kulturalnya serta mengomunikasikan pemahamannya tersebut secara efektif dan efisien. Dengan demikian, esensi dari empati kultural adalah kemampuan individu untuk merasakan dan memahami orang lain yang berbeda latar belakang etnografik (suku, bangsa), 
demografik (usia, gender, gaya hidup/kebiasaan), status dan afiliasinya serta mengomunikasikan pemahamannya tersebut secara efektif dan efisien.

Empati kultural (budaya) dalam bimbingan dan konseling merupakan salah satu unsur yang sangat penting. Mengingat proses konseling merupakan sebuah bantuan melalui interaksi antara dua orang yang berbeda latar belakang budaya. Salah satu masalah yang sering muncul adalah kurangnya rasa empati dalam berkomunikasi yang bisa menyebabkan kesalahpahaman interaksi komunikasi sehingga konseli frustasi dan tidak ada manfaat yang dihasilkan dari proses konseling tersebut.

Berdasarkan dari teori-teori yang dikembangkan para peneliti di atas maka kajian ini diarahkan pada riset empati kultural yang dikembangkan oleh Ridley dan Lingle (1996) dengan alat ukur yang meliputi tiga komponen atau aspek, yaitu kognitif, afektif dan komunikatif dan mengadaptasi SEE (Scale Ethnocultural Empati) yang digagas Wang et al (2003). Adapun arah riset ini dalam bimbingan dan konseling adalah untuk mengkaji Empati budaya yang merupakan kemampuan konselor untuk memahami permasalahan konseli, melihat melalui sudut pandang konseli dan latar belakang budayanya, peka terhadap perasaan-perasaan konseli sehingga konselor mengetahui dan memahami bagaimana konseli merasakan perasaannya. Riset ini mendeskripsikan bagaimana profil empati kultural pada mahasiswa, baik gambaran umum empati kultural mahasiswa, maupun empati kultural mahasiswa berdasarkan jenis kelamin, semester, latar belakang pendidikan (sekolah), dan asal daerah.

\section{METODE}

Metode yang digunakan dalam penelitian ini adalah metode deskriptif dengan pendekatan kuantitatif. Pendekatan ini dirancang untuk menjawab pertanyaan penelitian secara spesifik dengan menggunakan analisis statistik. Penelitian ini dilaksanakan di Fakultas Tarbiyah dan Keguruan Universitas Islam Negeri Sunan Gunung Djati Bandung. Populasinya adalah seluruh mahasiswa semester tiga dan 5. Metode penarikan sampel dengan menggunakan teknik quota sampling dengan proporsi $50 \%$ dari mahasiswa semester tiga dan 5. Asumsi pemilihan mahasiswa semester tiga dan 5 karena sudah mengalami proses interaksi dengan teman sebaya selama satu tahun lebih. Populasi di bawah 100 dapat digunakan sampel 50\% dan jika berada di 100 sampai 1000, maka 
digunakan sampel 15-50\% dari jumlah populasi (Surakhmad, 1998, p. 100). Penelitian ini menggunakan populasi sebanyak 530 sehingga sampel yang digunakan 15\% dari 530 mahasiswa adalah 79,5 dibulatkan menjadi 80 mahasiswa, tetapi yang diambil jadi sampel 83 mahasiswa.

Data yang dikumpulkan perihal profil empati kultural mahasiswa, instrumen yang digunakan dalam penelitian ini adalah angket skala empati kultural dengan mengadaptasi skala yang dikembangkan Wang et.al (2003) berdasarkan konstruk skala empati etnokultural. Skala ini berentang dari angka 1 yang paling rendah sampai angka 5 yang tertinggi. Kisi-kisi instrumen penelitian ini terdiri dari tiga aspek atau dimensi yaitu aspek kognitif, afektif dan komunikatif dengan subaspek: pengambilan perspektif dan kesadaran empatik (kognitif), menerima perbedaan budaya (afektif) dan ekspresi dan perasan empatik (komunikatif). Setelah itu peneliti menyebarkan instrumen kepada 100 orang dan yang diterima sebanyak 83 orang.

Instrumen angket dengan 26 item diuji validitasnya dengan menggunakan teknik kolerasi item total product moment dan diperoleh 15 soal yang valid dan 11 soal tidak valid. Sedangkan uji reliabilitasnya dengan menggunakan rumus cronbach's alpha dan dilakukan dengan bantuan software SPSS versi 17. Analisis data dilakukan untuk menjawab beberapa pertanyaan tentang empati kultural yang menghasilkan data ordinal. Keseluruhan proses analisis statistik ini mengunakan bantuan software SPSS Versi 17 dan untuk melihat profil atau gambaran umum empati kultural digunakan 3 kategori, yaitu skor $\geq 95$ kategori tinggi, skor 59-94 kategori sedang dan skor $\leq 58$ berkategori rendah. Dengan skor maksimum 109 dan skor minimum 61.

\section{HASIL DAN PEMBAHASAN}

Secara umum diketahui bahwa empati kultural mahasiswa UIN Sunan Gunung Djati Bandung semester tiga dan 5 berada pada kategori sedang dengan skor rata-rata 83,84.berkategori sedang dengan skor rata-rata 83,84, sehingga dengan temuan tersebut, empati kultural mahasiswa harus dikembangkan lagi. Berdasarkan jenis kelamin, empati kultural mahasiswa berkategori tinggi didominasi oleh mahasiswa laki-laki sebanyak (25\%), sedangkan perempuan (14\%), empati berkategori sedang didominasi mahasiswa perempuan (65\%), sedangkan laki-laki (58\%), empati berkategori rendah didominasi mahasiswa 
perempuan juga (21\%) sedangkan laki-laki (17\%). Seperti dapat dilihat di Tabel 1 dan Tabel 2.

Adapun data yang diperoleh melalui angket juga menunjukkan bahwa empati kultural mahasiswa berdasarkan semester yang berkategori tinggi didominasi oleh mahasiswa semester tiga sebanyak (17\%), sedangkan semester lima (13\%), empati berkategori sedang didominasi mahasiswa semester tiga (70\%), sedangkan semester lima (60\%), empati berkategori rendah didominasi mahasiswa semester lima (29\%) sedangkan semester tiga (17\%). Lebih jelasnya dapat dilihat di Tabel 3 dan Tabel 4.

Tabel 1. Jumlah Kategori Empati Mahasiswa Berdasarkan Jenis Kelamin

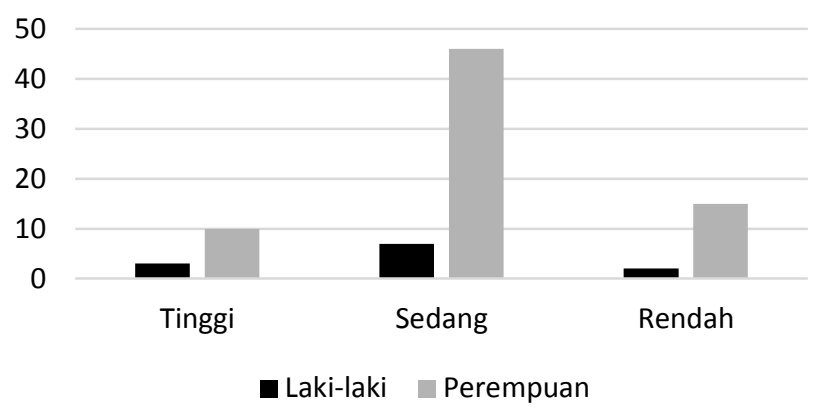

Tabel 2. Persentase kategori Empati Mahasiswa Berdasarkan Jenis Kelamin

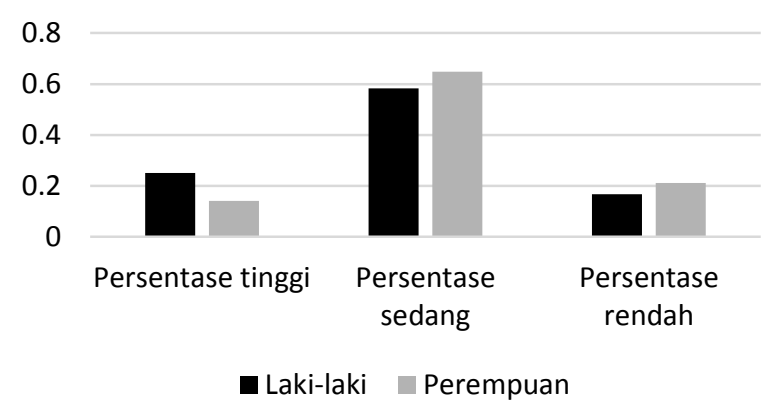

Tabel 3. Jumlah Kategori Empati Mahasiswa Berdasarkan Semester 


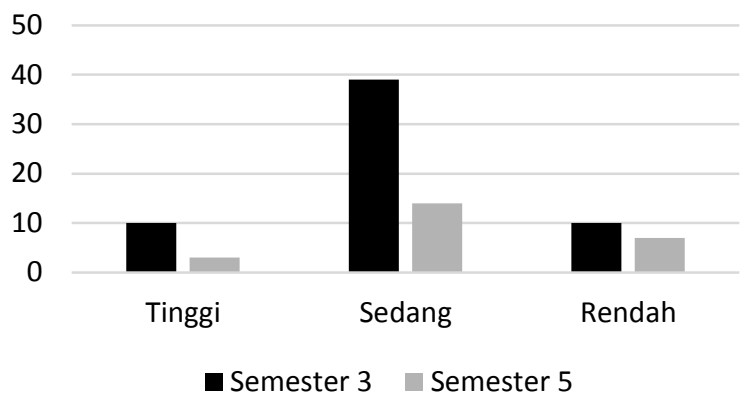

Tabel 4. Persentase Kategori Empati Mahasiswa Berdasarkan Semester

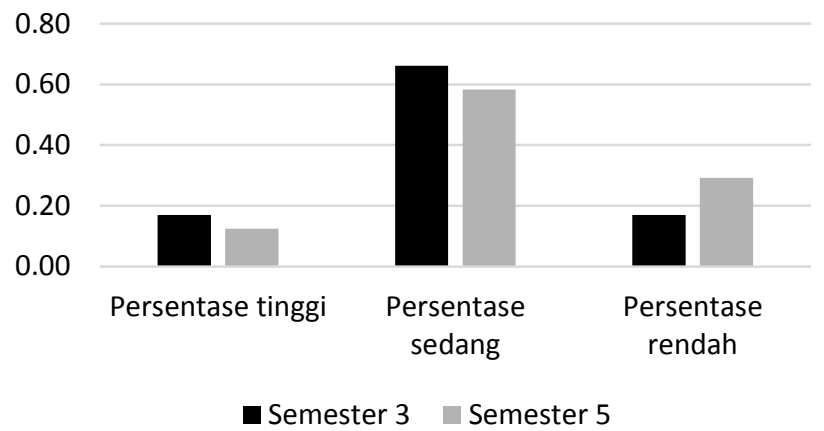

Dari data yang diperoleh melalui angket juga menunjukkan bahwa empati kultural mahasiswa berdasarkan latar belakang sekolah yang berkategori tinggi didominasi oleh mahasiswa berasal dari MA (Madrasah Aliyah/pesantren) sebanyak (17\%), sedangkan mahasiswa berasal dari SMA (14\%), empati berkategori sedang didominasi mahasiswa berasal dari MA (67\%), sedangkan mahasiswa berasal dari SMA (57\%), empati berkategori rendah didominasi mahasiswa mahasiswa berasal dari SMA (33\%) sedangkan mahasiswa berasal dari MA (17\%). Lebih jelasnya dapat dilihat di Tabel 5 dan Tabel 6.

Adapun data yang menunjukkan bahwa empati kultural mahasiswa berdasarkan asal daerah (geografis) yang berkategori tinggi didominasi oleh mahasiswa berasal dari desa sebanyak (18\%), sedangkan mahasiswa berasal dari kota sebanyak (13\%), empati berkategori sedang didominasi mahasiswa berasal dari desa (68\%), sedangkan mahasiswa berasal dari kota (59\%), empati berkategori rendah didominasi mahasiswa mahasiswa berasal dari kota $(28 \%)$ sedangkan mahasiswa berasal dari desa (14\%). Lebih jelas dapat dilihat di tabel 7 dan 8 .

Tabel 5. Jumlah Kategori Empati Mahasiswa Berdasarkan Latar Belakang Pendidikan (Sekolah) 


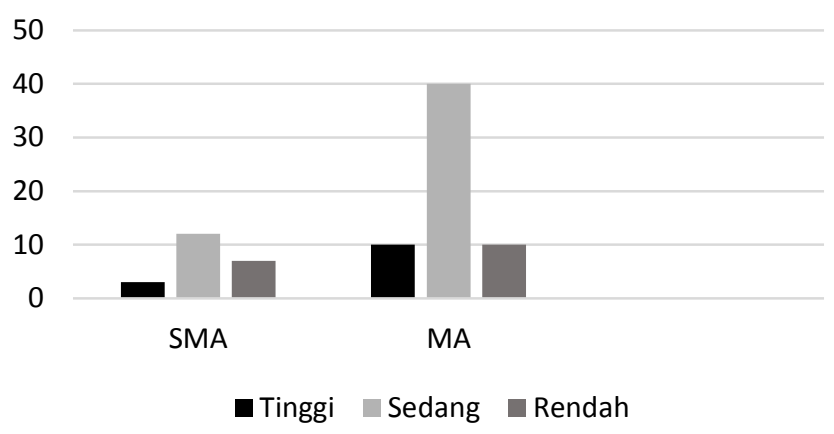

Tabel 6. Persentase Kategori Empati Mahasiswa Berdasarkan Latar Belakang Pendidikan (Sekolah)

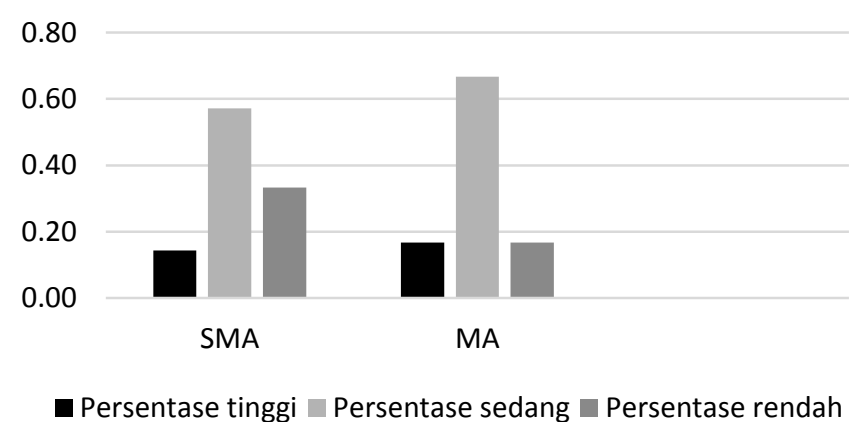

Tabel 7. Jumlah Kategori Empati Mahasiswa Berdasarkan Asal Daerah

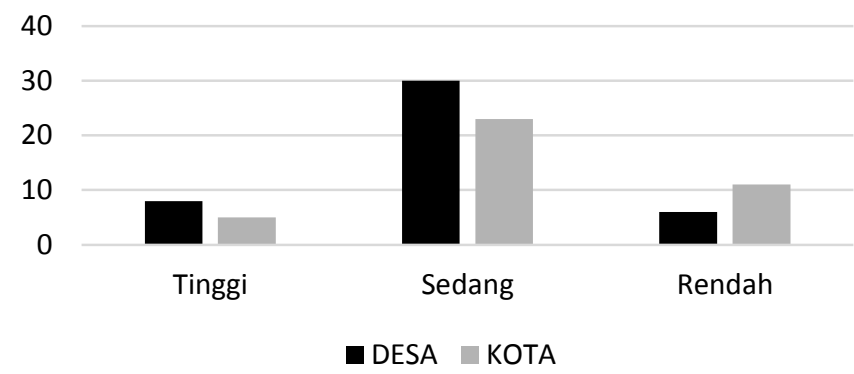

Tabel 8. Persentase Kategori Empati Mahasiswa Berdasarkan Asal Daerah 


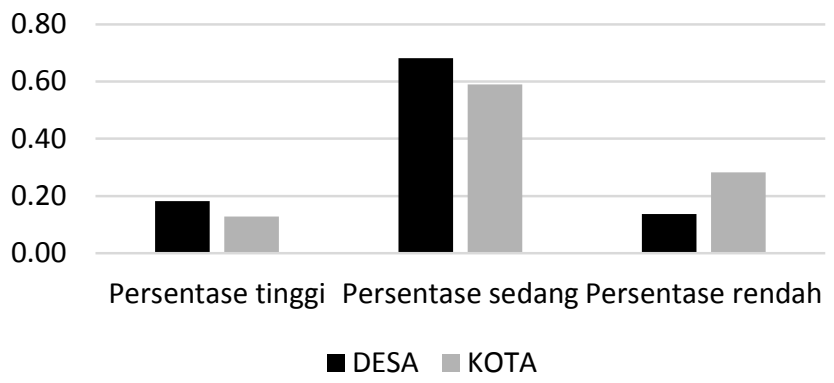

Hasil temuan di atas menunjukkan bahwa empati kultural mahasiswa berdasarkan jenis kelamin didominasi oleh mahasiswa perempuan (65\%) berkategori sedang, hanya saja dengan persentase yang tidak jauh berbeda dengan mahasiswa laki-laki (58\%). Kondisi ini menunjukkan bahwa empati kultural mahasiswa perempuan lebih tinggi dibandingkan laki-laki walaupun perbedaannya tidak terlalu signifikan. Empati kultural mahasiswa berdasarkan semester didominasi oleh mahasiswa semester tiga (70\%) dan semester lima (60\%), kondisi ini menunjukkan bahwa empati mahasiswa semester tiga lebih tinggi daripada mahasiswa semester lima. Adapun empati kultural mahasiswa berdasarkan latar belakang sekolah didominasi oleh mahasiswa yang berasal dari MA (67\%). Sedangkan, empati kultural mahasiswa berdasarkan asal daerah menunjukkan bahwa empati kultural mahasiswa berkategori sedang didominasi oleh mahasiswa yang berasal dari desa, atau dengan kata lain empati kultural mahasiswa yang berasal dari desa lebih tinggi dibandingkan dengan mahasiswa yang berasal dari kota.

Hasil temuan dapat disimpulkan bahwa profil empati kultural mahasiswa UIN Sunan Gunung Djati berkategori sedang lebih banyak didominasi oleh mahasiswa perempuan pada semester tiga dan berlatar belakang sekolah MA serta berasal dari desa. Keadaan ini selaras dengan penelitian Wang et al (2003) bahwa perempuan dengan empati yang tinggi terhadap budaya atau etnis mempunyai intensitas perilaku yang tinggi untuk menghadiri dan mempunyai persepsi yang positif terhadap berbagai macam program.

\section{Tinjauan Makna}

Ada lima teori yang menjelaskan teori empati (Eisenberg, 1987; Fesbach, 1997; Davis, 1996; Hoffman, 1998 \&2000; Batson, 1991, 1995, 1997), Teori-teori tersebut ada persamaan ada pula perbedaan. Persamaannya di antaranya, secara hakikat teori tersebut mendefinisikan empati sebagai kemampuan afektif dan bagian dari karakter atau kepribadian seseorang untuk memahami afektif dan 
kognitif orang lain, secara aspek memiliki dua komponen, yaitu afektif dan kognitif. Teori Fesbach, kognitif merupakan share respons emosional antara observer dan orang lain. Sedangkan Davis selain komponen afektif dan kognitif disertakan juga fenomena psikomotorik, sebagai komponen empati.

Eisenberg (2000) mendefinisikan empati sebagai kondisi emosional untuk memahami orang lain (respons afektif) dan perbedaannya menurut beliau ada empat bentuk respons empati, yaitu conditioning association, labelling, retrieving, elaborated cognitive network dan role taking. Eisenberg juga mengemukakan cara untuk mengajarkan empati melalui: induksi, nasihat moral dan modelling. Begitu juga Hoffman (2000) mendefinisikan empati mengacu pada kedua aspek, yaitu kognitif dan afektif. 1) Ia mendefinisikan empati sebagai kesadaran kognitif terhadap kondisi internal yang lain, 2) respons afektif yang dilakukan untuk orang lain dan ia lebih cenderung menggunakan definisi yang kedua. Batson juga sama secara hakikat mendefinisikan empati sebagai respons emosional sesuai dengan kondisi yang dilihat pada orang lain. Batson menyebut bahwa empati dapat menumbuhkan dorongan untuk menolong (altruis), tujuan dorongan itu untuk memberikan kesejahteraan bagi target empati (Taufik, 2012).

Meskipun pendapat para ahli tersebut menampakkan beberapa perbedaan makna empati, namun sejumlah persamaannya dapat disimpulkan pada dua hal: 1) Respons afektif kepada orang lain yang memerlukan sharing atas kondisi emosional yang bersangkutan; dan 2) Kemampuan kognitif diperlukan untuk memahami perspektif orang lain (perspective taking).

Sedangkan empati kultural dikemukakan oleh tiga teori, yaitu, teori dari Ridley \& Lingle (1996), Wang et al (2003), dan teori dari Pederson et al (2008). Secara hakikat ketiga teori tersebut memiliki persamaan dan perbedaan, baik dari komponen (aspek) dan bentuknya. Persamaannya secara hakikat, ketiga teori tersebut mendefinsikan empati kultural sebagai kecakapan individu (dalam hal ini konselor) yang dipelajari secara akurat memahami pengalaman- pengalaman diri orang lain (konseli) dari budaya yang berbeda, memahami informasi dan menginterprestasikan data-data kultural, dan mengkomunikasikan pemahamannya secara efektif dengan sikap/ permasalahan pada klien yang berbeda budaya baik secara individu maupun seting kelompok (kelompok etnik atau ras tertentu). Secara aspek pun ketiga teori tersebut sama-sama mengacu pada ketiga aspek, yaitu: afektif, kognitif dan komunikatif. 
Empati kultural menurut perspektif bimbingan dan konseling merupakan kemampuan belajar yang menekankan pentingnya komitmen terapis (konselor) untuk mengintegrasikan faktor-faktor budaya ke dalam tahapan terapi (konseling). Dengan kata lain, empati kultural merupakan kecakapan konselor yang dipelajari secara akurat memahami pengalaman- pengalaman diri klien dari budaya yang berbeda, memahami informasi dan menginterprestasikan datadata kultural, empati budaya juga melibatkan kemampuan konselor untuk mengkomunikasikan pemahamannya secara efektif dengan sikap/ permasalahan pada klien yang berbeda budaya (Ridley \& Lingle, 1996).

Empati kultural (budaya) juga merupakan sesuatu yang berdimensi jamak (multidimensional), yaitu mencakup aspek perseptual- affective- cognitivecommunicative process), dan memiliki dua bentuk, yaitu: 1) proses sperordinat: pemahaman empatik kultural (budaya), respons empati budaya dan cultural sensitivity dan 2) Proses subordinat: a. kognitif: perspective taking dan Cultural Self- Other Differentiation; b. Afektif dan c. Komunikatif (Ridley \& Lingle, 1997). Pendapat lain tentang bentuk empati, di antaranya: Empathetic Perspective-Taking, Acceptance of Cultural Difference, Empathetic Awareness dan Empathetic Feeling \& Expression (Wang, et al, 2003). Sedangkan, empati kultural (budaya) inklusif (Inclusive Culture Empathy) menjelaskan perspektif dinamis dengan menyeimbangkan persamaan dan perbedaan pada saat bersamaan, yaitu mengintegrasikan keterampilan yang dikembangkan untuk membina pemahaman yang komprehensif dan mendalam mengenai hubungan konseling dalam konteks budayanya (Pederson, 2008).

Dengan demikian empati kultural (budaya) inklusif ini juga secara pedagogi dapat diimplementasikan dalam mengintegrasikan keterampilan untuk membina pemahaman yang komprensif dan mendalam mengenai hubungan interpersonal antara pendidik dan peserta didik.

Empati ditinjau secara pedagogi merupakan disposisi profesional pendidik yang efektif. (Gordon 1999) dan aplikasinya dalam meningkatkan keefektifan pembelajaran siswa dengan latar belakang budaya yang berbeda (Carter 2009; Howard 2006, 2010; Dolby 2012; Warren, 2013). Hubungan empati dengan profesi mengajar (guru) berfokus pada interaksi manusia antara pendidik dan peserta didik. Aplikasi empati secara khusus, yaitu mengkaji disposisi profesional pembelajaran responsif secara kultural yang berisi pengetahuan, filsafat, atau sikap tentang pembelajaran.

\section{Tinjauan Nilai}


Empati merupakan dasar bagi hubungan interpersonal (Rogers, 1965). Secara teoretik empati melibatkan aspek afektif, kognitif, dan juga fenomena perilaku yang terjadi sebagai hasil dari pembongkaran Empathy Episode dengan mencakup empat konstruk, yaitu: antecedents, process, intrapersonal outcomes dan interpersonal outcomes. (Davis, 1996). Sedangkan Nancy Eisenberg mengembangkan cara untuk mengajarkan empati, melalui induksi, nasihat moral dan modelling dan Martin L. Hoffman (2000) mengemukakan bahwa empati adalah keterlibatan proses psikologis yang membuat sesorang memiliki feeling yang lebih kongruen dengan situasi orang lain daripada dengan situasi dirinya sendiri. Hoffman (2001) empati mengacu pada aspek kognitif dan afektif. Para teoretikus awal berpendapat bahwa empati merupakan "being" sesuatu yang dibawa individu sejak lahir atau faktor bawaan (genetis), sedangkan peneliti yang datang belakangan (terbaru) menemukan bahwa perlakuan-perlakuan yang ditujukan pada pembelajaran empati dapat meningkatkan kemampuan empati. Sebuah penelitian menjelaskan bahwa ketika guru menanamkan nilai-nilai empati kepada para siswanya, mereka lebih suka mengadopsi nilai-nilai empati itu dengan mencontoh perilaku guru dan menerapkan nilai-nilai yang dajarkan (Kremer \& Dietzen 1991, Kohn, 1991 dalam Taufik 2012). Sedangkan Haynes \& Avery (1979) menemukan bahwa pelatihan tentang nilai-nilai empati dapat digunakan untuk mengasah perasaan, pemahaman dan perilaku empati (Taufik 2012).

Penelitian yang dilakukan oleh Taufik (2009) bahwa permainan-permainan tradisional seperti Betengan dan Gobag Sodor dapat meningkatkan empati etnokultural pada anak-anak Jawa dan Tionghoa di Surakarta. Hasil penelitiannya menunjukkan bahwa permainan tradisional tersebut dapat memunculkan nilai-nilai kebaikan, khususnya nilai empati, seperti: sensitivitas, sportivitas, kerjasama dan pemahaman terhadap orang lain.

Temuan-temuan di atas semakin memperkuat bahwa kemampuan empati bukan hanya "being" (faktor genetis), tetapi juga dapat diperoleh melalui pembelajaran (becoming) yang diasah melalui interaksi dengan orang tua, guru, dan lingkungan sekitar. Empati juga dapat digunakan sebagai sarana untuk membangkitkan altruism (perilaku menolong). Sebagaimana penelitian yang dilakukan oleh Warnaken \& Tomasello (2009) bahwa hasil akhir yang terbaik dari empati adalah munculnya perilaku menolong. Dengan demikian, empati menjadi dasar atau pijakan (prediktor) untuk menumbuhkan nilai-nilai kebaikan lain, seperti sikap menolong (altruis), toleransi, cinta, persahabatan, pemaafan, sharing, kecerdasan adversitas, dan perilaku prososial lainnya. Perilaku empati 
juga dapat mereduksi intoleransi, konflik, diskriminasi dan meningkatkan pemahaman, rasa hormat, dan toleransi antara manusia dengan perbedaan etnis dan latar belakang budaya (Wang et al., 2003).

Pettigrew \& Tropp (2008) dalam metaanalisisnya menjelaskan perihal lebih dari 500 studi menemukan bahwa meningkatkan pengetahuan tentang luar kelompok, mengurangi kecemasan tentang kontak antarkelompok dan meningkatkan empati dan perspektif taking merupakan ketiga mediator yang terpenting dalam menurunkan prasangka antarkelompok. Penelitian Batson et al, (1995, 1997) menyarankan bahwa menginduksi empati untuk anggota kelompok yang terstigma dapat mengurangi prasangka, stereotip, dan diskriminasi kelompok secara keseluruhan (Bhaskar, 2011).

\section{Tren Riset Empati Kultural}

Beberapa penelitian membahas konsep empati dalam seting budaya walaupun pengembangan konsep empati antarbudaya masih relatif baru dalam lapangan psikologi. Penelitian survey dari Nicole L. Cundiff, Joel T. Nadler dan Alicia Swan (2009) yang mengambil sampel 294 mahasiswa Midwestern University yang berdasarkan pada evaluasi pelatihan yang beragam dengan menggunakan skala empati (the Scale of Ethnocultural Empathy) dari Wang et al (2003).

Hasil hubungan yang signifikan diperoleh dalam penelitian ini, menunjukkan bahwa perempuan dengan empati yang tinggi terhadap budaya atau etnis mempunyai intensitas perilaku yang tinggi untuk menghadiri dan mempunyai persepsi yang positif terhadap berbagai macam program. Wang et al (2003) menyatakan bahwa istilah empati antarbudaya digunakan untuk konstruk yang begitu solid karena para ilmuwan menggunakan istilah yang berbeda-beda dalam Taufik (2012), seperti Crosscultural Empathy: ada tiga istilah, yaitu: 1) crosscultural receptivity (penerimaan lintas budaya) adalah kemampuan untuk menerima dan mendengarkan keberadaan orang lain, 2) pemahaman lintas budaya (pemahaman ini tidak hanya sekedar mengalami perasaan orang lain, tetapi juga merefleksikan perasaan-perasaan tersebut dan membandingkannya dengan perasaan-perasaan sendiri, 3) kolaborasi lintas budaya; pemberian treatment terapis yang empatik cenderung untuk membangun hubungan yang kolaboratif (Dyche \& Zayas, 2001).

Penyebutan lain dari empati antarbudaya adalah Emphatetic Multicultural Awareness (Junn et al, 1995), Cultural Role Taking (Scoot \& Brodovsky, 1990), Ethnic perspective taking; Quintana mengembangkan model level kemampuan Ethnic perspective taking yang menggabungkan temuan kecenderungan afektif 
dan kognitif dalam penelitian mengenai respons anak-anak terhadap etnis dan budaya (Quintana, 1994). Ada juga yang disebut Ethnoterapeutic Empathy (EthE). EthE melahirkan sensitivitas terhadap kondisi-kondisi klien yang datang dari latar belakang budaya yang berbeda. Sensivitas ini penting untuk menseleraskan diri terapis kepada klien (Parson, 1993). Kemudian Cultural Empathy; Ridley dan Lingle menggambarkan Cultural Empathy ini sebagai kemampuan belajar. Mereka menekankan pentingnya komitmen terapis untuk mengintegrasikan faktor-faktor budaya ke dalam tahapan-tahapan terapi. Model ini terdiri dari tiga proses subordinat, yaitu: kognitif, afektif, dan komunikatif (Ivey et al., 1987); (Ridley \& Lingle, 1996). Terakhir yang paling mutakhir dikembangkan oleh Wang et al (2003) disebut Ethnocultural Empathy (EE).

Ethnocultural Empathy dibangun berdasarkan teori-teori empati secara umum dan teori-teori empati secara khusus berkaitan dengan budaya. Mereka mendefinisikannya sebagai kemampuan belajar dan keahlian pribadi yang berkaitan dengan kepribadian tertentu pada orang-orang dari etnis atau ras tertentu. EE ini dikembangkan dari Cultural Empathy sebagaimana asal alat ukur ini dibangun atas tiga kompunen, yaitu kognitif, afektif, dan komunikatif. Sedangkan di Indonesia telah dilakukan dan dikembangkan penelitian Empati Etnokultural pada Etnis Jawa dan Tionghoa yang diteliti oleh Taufik (2009).

Beberapa studi yang meneliti kompetensi konseling multikultural telah difokuskan pada empati dan berempati budaya (Brammer, Abrego, \& Shostrum, 1993; Chung \& Bemak 2002; Egan, 1998; Patterson \& Welfel 1994). Penelitian lain dari Nicole L. Cundiff, Joel T. Nadler dan Alicia Swan (2009) dengan sampel 294 mahasiswa Midwestern University. Penelitian ini menggunakan metode kuantitatif melalui survey yang berdasarkan pada evaluasi beragam pelatihan dengan menggunakan beberapa skala. Skala empati yang digunakan adalah the Scale of Ethno cultural Empathy dari Wang et al. Hasil hubungan yang signifikan diperoleh dalam penelitian ini, menunjukkan bahwa perempuan dengan empati yang tinggi terhadap budaya atau etnis mempunyai intensitas perilaku yang tinggi untuk menghadiri dan mempunyai persepsi yang positif terhadap berbagai macam program. Sebagian besar penelitian tersebut difokuskan pada anak-anak dan orang dewasa, walaupun ada penelitian tentang empati yang difokuskan pada remaja, khususnya remaja akhir (mahasiswa), tetapi masih minim. Dengan demikian perlu diadakan kajian atau penelitian pengembangan empati untuk mahasiswa di perguruan tinggi.

\section{Upaya Praksis Penggunaan Empati}


Secara praksis penggunaan empati ada pada multidisiplin ilmu, antara lain digunakan dalam pedadogi dan bimbingan dan konseling. Empati merupakan salah satu aspek penting dalam persiapan mengajar bagi profesional guru dalam seting sekolah dengan perbedaan budaya. (Aspy 1972, 1975; Black \& Phillips 1982; Redman 1977; Tettegah \& Anderson 2007) Empati juga merupakan disposisi profesional guru yang efektif dalam seting urban. (Gordon 1999) dan aplikasinya dalam meningkatkan keefektifan pembelajaran siswa dengan latar belakang budaya yang berbeda (Carter 2009; Dolby 2012; Howard 2006, 2010; Warren, 2013). Hubungan empati dengan profesi mengajar (guru) berfokus pada interaksi manusia antara guru dan peserta didik. Aplikasi empati secara khusus, yaitu mengkaji disposisi profesional pembelajaran responsif secara kultural. Disposisi ini berisi pengetahuan, filsafat, atau sikap tentang pembelajaran (Johnson \& Reiman, 2007).

Sikap Empati adalah motif altruistik dalam layanan bimbingan dan konseling yang memandirikan. Empati menjadi sesuatu yang sangat penting untuk awal mula membentuk komunikasi ketika proses konseling dilaksanakan. Sikap empati konselor yang tinggi inilah yang akan mempengaruhi proses layanan bimbingan dan konseling yang diberikan. Konselor dengan sikap empati akan menciptakan suasana yang nyaman, terpercaya dan penuh kejujuran dalam proses konseling bagi konseli.

Konselor diharapkan dapat memahami permasalahan konseli secara lebih mendalam terhadap kondisi psikologis konseli. Jika konselor mampu memahami permasalahan konseli, melihat melalui sudut pandang konseli dan latar belakang budayanya, peka terhadap perasaan-perasaan konseli sehingga ia mengetahui dan memahami bagaimana konseli merasakan perasaannya, maka ia dapat mewujudkan hubungan teurapeutik yang berkualitas. Dengan demikian dapat memprediksi aktivitas yang akan dialami konseli dengan menjajaki perasaan dan sikapnya secara mendalam (Komalasari \& Wahyuni, 2011). Selain konselor memahami budaya konseli yang berbeda, juga konseli dapat memahami konseli lainnya yang berbeda budaya dalam seting kelompok.

Perspektif empati multikultural yang semakin diperlukan di tengah pendidikan, pelatihan, penelitian dan praktik konseling masa kini sehingga pendidikanpelatihan konselor perlu mengusahakan berbagai upaya (Trusty, Ng, \& Watts, 2005), yakni: 1) Pencurahan pengalaman emosional (attunement) hari demi hari; 2) Praktik pendisiplinan yang berpretensi mengajak individu memahami penderitaan psikologis orang lain; 3) Adanya teladan berulang akan tanggapan 
empatik yang tepat terhadap orang lain yang memerlukan. Ketiga upaya pokok tersebut perlu ditumbuhkembangkan dalam iklim relasi (hubungan) pada setiap pendidikan-pelatihan para calon konselor agar iklim relasi ini dapat berperan menumbuhkembangkan kemampuan empati setiap calon konselor sehingga mampu mewujudkan proses konseling yang efektif.

Penelitian ini memiliki keterbatasan, karena pada dasarnya belum final. Penelitian ini tidak sampai pada meneliti bagaimana faktor-faktor yang mempengaruhi empati kultural secara lebih mendalam, tetapi, hanya meneliti pada bagaimana profil empati kultural mahasiswa, khususnya di UIN Sunan Gunung Djati Bandung, sehingga penting adanya penelitian lanjutan.

\section{SIMPULAN}

Empati kultural sangat dibutuhkan dalam relasi interpersonal dan hubungan terapeutik (konseling) sebagaimana dikemukakan dalam teori humanistik dan Rogers bahwa empati merupakan salah satu unsur kunci dalam menciptakan hubungan teurapetik. Teori empati merupakan multidimensional dan juga sebagai dasar atau pijakan untuk menumbuhkan nilai-nilai prososial lain, seperti perilaku menolong (altruis), kerjasama, pemaafan, kecakapan adversitas, toleransi, cinta, persahabatan dan lain sebagainya.

Secara praksis dalam iklim terapi atau konseling yang disertai empati menjadi syarat utama yang akan mendukung bagi tumbuhnya konsep diri positif pada konseli sehingga ia dapat mengatasi permasalahannya sendiri. Maka perlu dilakukan upaya melatih dan mengembangkan empati, khususnya empati kultural seseorang sedini mungkin, baik di keluarga-keluarga, sekolah-sekolah dan lembaga-lembaga pendidikan guna mengembangkan kemampuan empati, khususnya empati kultural dalam hubungan antar manusia.

Implementasi pelaksanaan bimbingan dan konseling di perguruan tinggi (PT) melalui kolaborasi antara berbagai sivitas akademik di PT dengan perlu mempertimbangkan dan memperhatikan kebutuhan (need assessment) dan keragaman latar belakang atau karakteristik mahasiswanya. Di antaranya keragaman latar belakang budaya mahasiswa. Penelitian ini dapat dijadikan bahan informasi awal dan wawasan pengetahuan tambahan tentang empati kultural dalam konteks berbagai isu dan dasar konseptual. Sehingga, penting juga diteliti hubungan antara interaksi (perilaku) individu dengan budaya atau pengaruh budaya terhadap interaksi individu. Dengan demikian, tren penelitian 
empati kultural dalam bimbingan dan konseling masa kini di Indonesia dapat semakin berkembang.

\section{REFERENSI}

Allport, G.W. (1965). Pattern and Growth in Personality. New York: Holt, Rinehart \& Winston.

Aspy, D. N. (1972). An investigation into the relationship between teachers' factual knowledge of learning theory and their classroom performance. Journal of Teacher Education, 23(1), 21-24.

Aspy, D. N. (1975). The relationship between selected student behavior and the teacher's use of interchangeable responses. The Journal of Humanistic Counseling, 14(1), 3-11.

Bhaskar, T. (2011). Assessing effectiveness of multicultural readings in increasing ethnocultural empathy for undergraduate students. Disertasi. The University of Tennessee, Knoxville.

Berry, J. W., Poortinga, Y. H., Segall, M. H., \& Dasen, P. R. (1999). Psikologi lintas budaya: Riset dan aplikasi. Jakarta: Penerbit Gramedia Pustaka Utama.

Borba, M. (2008). Building moral intellegence: The seven essential vitures that teach kids to do the right thing. Alih Bahasa: Lina Yusuf. Jakarta: Gramedia Pustaka Utama.

Carter, P. (2009). Equity and empathy: Toward racial and educational achievement in the Obama era. Harvard Educational Review, 79(2), 287297.

Cundiff, N. L., Nadler, J. T., \& Swan, A. (2009). The influence of cultural empathy and gender on perceptions of diversity programs. Journal of Leadership \& Organizational Studies, 16(1), 97-110.

Dolby, N. (2012). Rethinking multicultural education for the next generation: The new empathy and social justice. New York: Routledge.

Dyche, L., \& Zayas, L. H. (2001). Cross-cultural empathy and training the contemporary psychotherapist. Clinical Social Work Journal, 29(3), 245258.

Eisenberg, N \& Strayer, J. (1987). Empathy and its development. Cambridge: Cambridge University Press.

Eisenberg, N. (2000). Emotion, regulation, and moral development. Annual review of psychology, 51(1), 665-697. 
Goleman, D. (1995). Emotional intelligence. New York: Bantam Books.

Hoffman, M. L. (1987). The contribution of emphaty to justice and moral judgement. In N. Eisenberg \& J. Strayer (Eds.). Empathy and Its Development. (pp. 47-80). Cambridge: Cambridge University Press.

Hoffman, M. L. (2000). Empathy and moral development: Implications for caring and justice. Cambridge: Cambridge University Press.

Howard, G. (2006). We can't teach what we don't know: White teachers, multiracial Schools. New York: Teachers College Press.

Howard, T. C. (2010). Why race and culture matter in schools: Closing the achievement gap in America's classrooms. New York: Teachers College Press

Komalasari, G., \& Wahyuni, E. (2011). Teori dan teknik konseling. Jakarta: Indeks

McAllister, G., \& Irvine, J. J. (2002). The role of empathy in teaching culturally diverse students: A qualitative study of teachers' beliefs. Journal of Teacher Education, 53(5), 433-443.

Parsons, S. C., \& Brown, P. U. (2001). Educating for diversity: An invitation to empathy and action. Action in Teacher Education, 23(3), 1-4.

Rasoal, C., Eklund, J., \& Hansen, E. M. (2011). Toward a conceptualization of ethnocultural empathy. Journal of Social, Evolutionary, and Cultural Psychology, 5(1), 1.

Pedersen, P. B., Crethar, H. C., \& Carlson, J. (2008). Inclusive cultural empathy: Making relationships central in counseling and psychotherapy. Washington, DC: American Psychological Association.

Redman, G. L. (1977). Study of the relationship of teacher empathy for minority persons and inservice human relations training. The Journal of Educational Research, 70(4), 205-210.

Ridley, C.R., \& Lingle, D.W. (1996). Cultural empathy in multicultural counseling: A multimensional process model. In P. B. Pedersen \& .G. Draguns (Ed.), Counseling Across Cultures. Thousands Oaks: Sage.

Rogers, C. R. (1975). Empathic: An unappreciated way of being. Counseling Psychologist.

Surakhmad, W. (1998). Pengantar penelitian ilmiah: Dasar metode teknik. Bandung: Tarsito.

Sutardi, Tedy. (2007). Antropologi mengungkap keragaman budaya. Bandung: Setia Purna Inves 
Taufik. (2012). Empati pendekatan psikologi sosial. Jakarta: Rajawali Press.

Tettegah, S., \& Anderson, C. J. (2007). Pre-service teachers' empathy and cognitions: Statistical analysis of text data by graphical models. Contemporary Educational Psychology, 32(1), 48-82.

Trusty, J., Ng, K. M., \& Watts, R. E. (2005). Model of effects of adult attachment on emotional empathy of counseling students. Journal of Counseling \& Development, 83(1), 66-77.

Yusupov, I. (1995). Psychology of empathy (Theoretical and practical aspects). St-Petersurg, Russia: St-Peteresburg State University.

Wang, Y. W., Davidson, M. M., Yakushko, O. F., Savoy, H. B., Tan, J. A., \& Bleier, J. K. (2003). The scale of ethnocultural empathy: development, validation, and reliability. Journal of counseling psychology, 50(2), 221.

Warren, C. A. (2013). Towards a pedagogy for the application of empathy in culturally diverse classrooms. The Urban Review, 46(3), 395-419. 